\title{
Tailoring for Development: China's Post-Crisis Influence in Global Financial Governance
}

\author{
Julian Gruin (Amsterdam Institute for Social Science Research, University of Amsterdam; Department of \\ Politics and International Studies, University of Warwick) \\ Peter Knaack (Blavatnik School of Government, University of Oxford) \\ Jiajun Xu (Institute of New Structural Economics, National School of Development, Peking University)
}

\begin{abstract}
China's increasing engagement in global financial governance since the 2008 crisis has potentially significant ramifications for global financial rule-making and standard-setting. This article presents a novel analysis of China's growing influence on the international stage and its consequences for the financial rules and standards that constrain policymakers in developing countries. We draw upon literature from international political economy and development studies to develop a framework for assessing whether China's rise has catalysed a shift in global financial governance towards a tailored approach that responds to country-specific developmental circumstances and needs. We argue that China's status as a rising power that still has idiosyncratic developmental priorities is leading it to push for rules and standards that are more flexible and sensitive to specific national development conditions. We illustrate this argument in three case studies, deploying the framework to explain variation in the post-crisis evolution of rules in prudential banking regulation, capital flow management, and debt sustainability surveillance.
\end{abstract}

\section{Policy Implications}

While insisting on cross-border harmonization in financial rules and standards is a convenient choice for the international financial institutions (IFIs), they should consider moving further away from a onesize-fits-all approach that unduly constrains the policy choices of developing countries.

China's growing influence in global financial governance enables developing country governments to exert more discretion in tailoring financial policies to their development needs and idiosyncratic circumstances.

As financial policy discretion is a mixed blessing, policymakers need to devise guidelines that harness the benefit of greater autonomy while safeguarding against the risk of a "race-to-thebottom".

Decisionmakers in IFIs can take lessons from China's domestic development challenges to formulate a unique set of principles for sound financial management that is agnostic regarding the institutional setup to achieve it. 


\section{Introduction}

China's growing engagement with global financial governance (GFG) has led to a rapidly burgeoning literature on the impact of China's rise upon the US-led hegemonic international economic order (Henning and Walter 2016; Xu 2017; F. Zhang 2017). Political economists disagree on the degree to which the global financial crisis of 2007-9 has precipitated a change in vision of how to organise and govern global capitalism, and China's role in this process. But while many analysts focus on the repercussions of changes in GFG for the world's core economies, their effect on developing countries in the periphery has been largely neglected.

Meanwhile, a parallel debate focuses on what kind of financial policies decisionmakers in developing countries should adopt to foster growth and prosperity. Development scholars and practitioners weigh the advantages and disadvantages of a shift away from a singular set of global best practices and towards an approach that lets developing countries tailor monetary, fiscal, prudential regulatory and other financial policies to their specific national developmental needs and conditions. Today's rules and standards of GFG may endorse such a tailored approach to development to a greater degree than before the financial crisis, but it is unclear what role China's rise has played in this transformation.

In this article we seek to bridge these two fields of study-international political economy and development studies-to investigate whether China is influencing global financial governance by promoting a tailored approach, one sensitive to the different needs of countries at different stages of development. We develop a novel analytical framework to map the universe of possible scenarios regarding China's influence on the ways in which global financial rules and standards constrain choice of financial policy in developing countries. We focus on China's rise within GFG because for the first time since the World War II, a rising power is both willing and able to push for a set of institutions that allow developing countries to tailor financial policies to their idiosyncratic needs and circumstances.

To probe the plausibility of these propositions, we present the results of three case studies on different areas of GFG, namely prudential banking regulation, capital flow management, and debt sustainability surveillance. We show that the rules of GFG emphasized cross-border policy harmonization and consistency before the crisis. Our study reveals that while policymakers in Beijing endorse a departure from such harmonization in the three cases under analysis, China's influence in GFG covaries with the endorsement of a tailored approach across issue areas.

Following this introduction, we survey the relevant literature in international political economy and development studies to extract the building blocks for designing our analytical framework at the intersection of the two fields. The following section analyses the uniqueness of China as a rising power in GFG from a development perspective. The subsequent case studies analyse financial one-size-fits-all rules in three issue areas and trace China's role in the promotion of a more tailored approach. The article concludes with discussion of the limitations of this study, the normative ambiguity of policy tailoring, and avenues for future research. ${ }^{i}$

\section{Analytical Framework: China's rise and a tailored approach in GFG}

Debates surrounding the evolution of GFG in the wake of the global financial crisis can be understood as spanning a two-dimensional field. The first dimension focuses on the degree to which China has risen to prominence in the key organizations of GFG. Scholars disagree over the extent to which the global financial crisis has catalyzed a shift in global financial power away from the $G 7$ and towards emerging market economies in general and China in particular. The second dimension reflects change not within the system but of the system itself. It is concerned with a deeper systemic change in the relationship between financial markets and the state as codified in the rules and standards of GFG. Many observers argue that pre-crisis GFG embodied a neoliberal consensus, granting primacy to market forces as the superior organizing principle of the global economy. But opinions diverge as to whether post-crisis GFG endorses state interventionism to a greater degree or not.

The dimensions of power transition and systemic change are of course intertwined. But to lend greater clarity to the debate, and to contextualize our arguments concerning China's rising influence in GFG, we map the different narratives of post-crisis change in the field of IPE along these two dimensions in Table 1. 
Table 1: Scenarios of China's Influence upon GFG

\begin{tabular}{lll}
\hline \hline & Minimal systemic change & Significant systemic change \\
\hline \hline Minimal power transition & $\begin{array}{l}\text { (1) Western hegemony endures } \\
\text { through status quo crisis }\end{array}$ & $\begin{array}{l}\text { (2) Endogenous shift in nature of } \\
\text { financial } \begin{array}{l}\text { governance } \\
\text { without }\end{array}\end{array}$ \\
Significant power transition & $\begin{array}{ll}\text { (3) China rises but is 'socialized' into } \\
\text { existing order }\end{array}$ & $\begin{array}{l}\text { (4) China rises and affects change in } \\
\text { nature of financial governance }\end{array}$ \\
\hline \hline
\end{tabular}

The first narrative questions the belief that China represents a challenger either to US financial hegemony or to the dominance of neoliberal capitalism. In a prominent account, Helleiner (2014) argues that changes towards either a Polanyian (1957) 're-embedding of the market' or to greater Chinese prominence in the global financial order following the 'status quo crisis' were modest at best, dispiriting at worst.

The second narrative places deeper importance on the changes that have taken place within the global financial order over the past decade, but does see China as playing a meaningful role in inducing these changes. Whether a genuine Polanyian countermovement, or attempts at 'system maintenance' by entrenched economic and policy elites (see Baker 2014), post-crisis efforts to reshape global finance have been largely endogenous to existing institutions that China had-and continues to have-relatively little role in constructing and reforming (Stiglitz 2010).

The third narrative posits that China, having embarked upon its economic and financial transformation within an interdependent and globalized world economy, is destined to adopt and mirror existing institutions and norms of the global neoliberal order (Ikenberry 2008; Kahler 2013; Steinfeld 2010), at the very most constituting a 'reform-minded status quo power' (Xiao 2015) or 'pragmatic and institutionally pluralist' (Ferdinand and Wang 2013). The existing institutions and norms have exhibited significant resilience in the face of the crisis so that there is no reason to expect that the entry of Chinese actors and institutions into this order will fundamentally disrupt them.

The final narrative holds that China's rise has precipitated systemic changes in the nature of the global financial order that China is ushering in a qualitatively different vision for how to organise and govern global capitalism (Bremmer 2010; Xu 2017), reshaping the dynamics of transnational financial integration and governance. This has spurred debates on the nature of the 'China model' as a mode of development (Beeson and Li 2015; Breslin 2011; Horesh and Lim 2017; Kennedy 2010), and of China's preferences for regionally oriented institutional architectures of GFG (Sohn 2013; see also Helleiner and Pagliari 2011).

Recent moves have advanced beyond generalizations as to China's preferences towards GFG, for example by arguing that rather than a 'China model', China's core national objective of economic development drives inconsistent stances across different issue areas, some of which support the status quo, and others which seek to revise it (F. Zhang 2017; Güven 2016). But China is not alone regarding economic development as its core national interest. Developing countries with and without voice in GFC agree on this objective, but they are facing vastly different conditions and challenges to achieve it. This raises the question of whether China's rise in GFG has repercussions for the extent to which developing countries are constrained by global financial rules and standards as they chart their country-specific path to economic development, tailoring and adapting financial policies to local conditions.

In sum, although IPE scholarship has made significant strides in analyzing the trajectory of postcrisis GFG from a variety of perspectives, is has mainly focused on its consequences for the advanced and major emerging economies that form the core of the global economy. Political economists have shed less light on the repercussions of China's rise in GFG for developing countries. We consider it therefore important to connect IPE debates over power transition with the question of how this power transition is affecting the capacity of developing countries to pursue nationally tailored developmental strategies and policies within GFG. Accordingly, we turn to development studies to provide another perspective on the impact of China's increasing engagement in GFG.

Over the past half-century, three generations of "big ideas" have dominated the field of development studies (Lindaver et al. 2002). Each generation contained a relatively coherent set of ideas regarding role of the government, capital accumulation, trade and integration, foreign capital, and foreign assistance in development. Formulated by development economists from elite universities and 
seemingly corroborated by contemporary experiences in developing countries, these big ideas shaped the narrative and policy descriptions in the core organizations of GFG in each phase.

Development thinking in the early post-war period was dominated by what is now called Old Structuralism: an understanding that global market forces operate to the detriment of developing countries unless they engage in a state-led, inward-oriented process of structural transformation (Prebisch 1950; Hirschman 1958). While this approach may have endorsed a one-dimensional notion of development along a predetermined sequence of stages (Rostow 1959), it contained an implicit recognition that developing countries face different types of challenges that merit corresponding sets of policy prescriptions.

The economic crises of the 1970s and 1980s challenged the Structuralist approach, ushering in a new generation of development thinking that highlighted the beneficial effects of market forces, liberalization, and international integration. The key feature from an institutional point of view was the belief that an effective, rules-based, and politically accountable bureaucracy is a necessary ingredient of successful development. Officials in international organizations started devising policies that would install such Weberian institutions in countries irrespective of income level and idiosyncratic circumstances. In other words, the second generation of big ideas in development thinking espoused a move away from country-specific adaptation and towards cross-border harmonization of rules and policies (North 1990).

Twenty years later, the development strategies of the second generation have failed to deliver the desired results. Many developing countries that were among the most fervent followers of the augmented Washington Consensus have experienced years of stagnation and even drastic setbacks in economic development due to macroeconomic crises. Development scholars of the current, third generation recognize that the strategy of "skipping straight to Weber" (Pritchett and Woolcock 2004, 193) failed to foster economic growth and prosperity. Moreover, while a certain set of institutions may undergird economic performance in advanced economies today, their development trajectory featured an co-evolutionary cycle of adaptive refashioning among market-building institutions and markets (Ang 2015). This understanding of institutional development calls into question the existence of a unique set of "good institutions" and "good policies" along with the merit of insisting on cross-border harmonization of policy advice to achieve them (Chang 2003; Chang and Grabel 2005). As Pritchett and Woolcock (2004, 193) note: "one size clearly will not fit all in countries as different as Canada, Chad, China, and Costa Rica".

Strikingly, while development scholars of the third generation agree on why previous development strategies were misguided, they refrain from devising a new set of big ideas to replace them. While the desire to interpret specific experiences (such as Korea's or China's growth miracles) as universal laws continues today, leading development thinkers argue that poor countries can grow only by overcoming their own, highly specific constraints. This notion is no instance of developmental nihilism, however. Rodrik for example insists on the existence of universal economic principles such as property rights and the rule of law. But these principles do not map onto unique institutional arrangements or policy prescriptions. Striking a balance between "anything goes" and a single set of best practices, development thinkers suggest the development of a "diagnostic tree for policy advice" akin to a doctor's diagnosis, taking into account country characteristics such as income level, status of growth, geography, political linkages, and strength of government (Rodrik 2001; Lindauer et al. 2002; Mukand and Rodrik 2005; Rodrik 2008).

Building on these foundations, Justin Lin Yifu's New Structural Economics acknowledges that competition in a well-functioning market is key to economic development, but that government facilitation is necessary to upgrade infrastructure, mitigate coordination problems and compensate firms that move up the value chain for the first mover information externalities they incur. Lin's approach also envisions developing countries tailoring development strategies in line with different development stages on their path towards economic structural transformation (Lin 2012).

Has this evolution in development thinking translated into concrete changes in the global rules and standards that govern financial policies in developing countries? And what role did China's rise in global financial governance play in this process? This key question has not received enough attention in the development studies literature to date. In combining scholarship from IPE and development studies, this article seeks to fill this lacuna by analyzing China's influence on the rules and standards of global financial governance that are of relevance for financial policies in developing countries in particular.

Our analytical framework as summarized in Table 2 lays out the universe of possible ways in which China's rise in GFG has affected developing countries along two dimensions. The first one borrows the notion of power transition from the IPE literature as referenced above. It maps the degree to which China's ascent in the old organizations of GFG and its role in the creation of new ones such as the Asian Infrastructure Investment Bank (AIIB) has translated into a power shift towards Beijing. The second dimension derives from the field of development studies, spanning a spectrum from a one-size-fits-all to a tailored approach to development. On one end of the spectrum, international policymakers insist on a single, harmonized set of rules and standards that applies to all developing countries with a maximum 
degree of cross-border consistency, irrespective of country-specific circumstances. Importantly, on the other end of the spectrum we do not envision a substantive difference in the rules and standards along the lines of competing "visions" of capitalism in IPE. For the purposes of our inquiry, what matters more than the substance is the scope of global financial rules and standards. In our analytical framework, tailoring does not mean that the institutions of GFG endorse certain policies, but rather that developing countries have the space to devise their own financial policies without being concerned whether they are congruent with those institutions or not.

Table 2: Scenarios of China's influence on the rules of GFG for developing countries

\begin{tabular}{lll}
\hline \hline & Harmonization of rules & Tailoring of rules \\
\hline \hline Minimal power transition & $\begin{array}{l}\text { (1) Western-led insistence on cross- } \\
\text { border harmonization endures }\end{array}$ & $\begin{array}{l}\text { (2) Third generation development } \\
\text { scholars embrace a tailored approach }\end{array}$ \\
\hline Significant power transition & $\begin{array}{ll}\text { (3) China rises but upholds cross- } \\
\text { border harmonization of rules }\end{array}$ & $\begin{array}{l}\text { (4) Departure from harmonization due } \\
\text { to China's insistence }\end{array}$ \\
\hline \hline
\end{tabular}

Scenario (1) portrays a world in which the institutions of global financial governance continue to insist on a singular and tightly delineated set of 'global best practices' that is applied to all developing countries. An alternative scenario (2) regards a move away from cross-border harmonization of rules and standards as the result of an intellectual embrace of the virtues of policy tailoring to country-specific circumstances. Such a change however would be attributable to the growing influence of the development economists that represent the third generation of development thinking as discussed above, rather than China's rise in global financial governance. A third scenario places greater emphasis on governance reform in the IFls, China's membership in global financial standard-setting bodies, and the creation of new development banks under China's leadership. Yet notwithstanding such power shifts, Chinese representatives in the organizations of global financial governance would uphold the status quo of constraining financial policies in developing countries in line with globally harmonized rules and standards. Finally, scenario (4) depicts a world in which China's rise in global governance would precipitate a retreat from one-size-fits-all policies and a push towards granting developing countries more space to devise domestic financial policies according to their idiosyncratic needs and circumstances.

It is important to recognize that the written rules and standards of GFG certainly do not represent the only and possibly not the binding constraint for developing countries. Financial policymakers in the periphery of the world economy are bound by the vicissitudes of cross-border financial flows, investor sentiment, and a multitude of other external economic factors that can be euphemistically subsumed under the label of market discipline. We therefore do not claim that explicit global financial rules are a representative sample of the constraints developing countries are facing. It would be an epistemologically daunting endeavor to identify changes in the tacit constraints for financial policies in all developing countries and attribute them to either the global financial crisis or China's rise with any degree of certainty. The analytical approach of this article does not only limit itself to explicit global financial rules, it also refrains from adopting a hypothesis-testing approach. Instead, we present a series of case studies on China's influence on particular rules of GFG that affect developing countries as an empirical probe of our analytical framework. Before doing so, a note on the particularities of China's rise in GFG is in order.

\section{Why China matters for policy tailoring in GFG}

China's rise within GFG is a necessary and unique case for study because for the first time after the World War II, a rising power is willing and able to push for a set of global financial rules and standards that allow developing countries to tailor their monetary, fiscal, and financial regulatory policies to their idiosyncratic needs and circumstances. A deeper inquiry into its development path helps us better understand China's distinctiveness in influencing GFG, as opposed to other major rising financial powers such as Germany and Japan.

First, the developmental strategies of 'catching-up' countries generally entail greater strategic state intervention as they try to integrate into global economy and promote their competitiveness. Developed countries today enjoy first-mover advantages, and have tended to 'kick away the ladder' following initial industrialization (Chang 2002). Developed economies therefore now have an inherent bias towards the harmonization of market-determined developmental strategies when writing global rules 
and standards. In contrast, developing countries tend to favour strategic state intervention in order to overcome uncertainty as they venture into new economic sectors (Mukand and Rodrik 2005), a strategy embraced by China in both its industrial and financial development. Hence, China like other catching-up economies has an inherent interest in preserving strategic space for manoeuvre.

Second, a close look at China's domestic development path reveals that in addition to deeper state involvement, Chinese development has consistently exhibited a decentralized and experimental mode of policymaking and governance (Naughton 1995; Walder 1995; Blecher and Shue 1996). This has been articulated in numerous ways, including 'local state corporatism' (Oi 1995), 'experimentalist policymaking' (Heilmann 2008), and 'directed improvisation' (Ang 2016), but one core theme is the adoption of a governance structure that enables localized institutional adaptation and innovation within an overarching set of developmental priorities and parameters (Chen and Naughton 2016; McNally 2012; Shen and Tsai 2016). The importance of these localized dynamics differentiates Chinese development from the archetypal East Asian developmental state that features highly centralized adaptive governance (Johnson 1982; Wade 2004). As Ang's (2016) study usefully illustrates, the value of governance that permits localized improvisation within centrally drawn parameters is an important Chinese contribution to developmental theory and practice more broadly. It enables retention of residual political authority, whilst producing the institutional architecture necessary for generating domestic growth drivers at the same time as effective strategic integration into transnational markets (Gruin 2016; McNally and Gruin 2017). There is every reason to expect that this emphasis on geographic and institutional variation in its own developmental experience is reverberating into China's engagement with GFG.

Third, China will continue to call for a more tailored approach to national financial policymaking for a sustained period of time. China continues to face a number of key developmental challenges that will compel it to 'think like a developing country' in the future, including vast regional and urban-rural disparities in China, as well the reform of its domestic financial system. Both the significant gap in the levels of industrialization across different parts of China and the level of financial development will demand a more tailored approach to integration into the global financial system for the years to come.

Last but not least, what differentiates China from previous rising powers such as Germany and Japan is that China is playing a significant role in global economic governance before it reaches a highly industrialized status because of the sheer size of its economy. China is the second largest economy in aggregate terms despite its relatively low per capita income, and its banking and financial system is one of the world's largest despite its low levels of 'sophistication' and transnational integration. For such an economy to exist at the centre of global economic and financial governance is unprecedented in the postWWII era.

\section{Towards greater tailoring: three emerging cases}

We present three different cases_-prudential banking regulation, capital flow management, and debt sustainability-as a first empirical probe of whether China's rise is relevant to deeper tailoring in GFG rules and standards. Although these cases are of course not representative of GFG as a whole, they are useful for this purpose, since they vary in the degree to which they exhibit our outcome of interest: a shift away from harmonization towards more scope for tailoring. For each, we first examine (1) the ways in which global rules and standards constrain financial policymakers in developing countries; (2) describe the pre-crisis status quo in terms of cross-border harmonization of these rules; (3) examine China's postcrisis engagement; and (4) evaluate the resulting extent of change in policy harmonization. In each of the cases we find indications of a relationship between China's influence and the extent to which post-crisis GFG embraces a tailored approach. Figure 1 presents a field in which our three cases, as well as potential others, might be situated. 


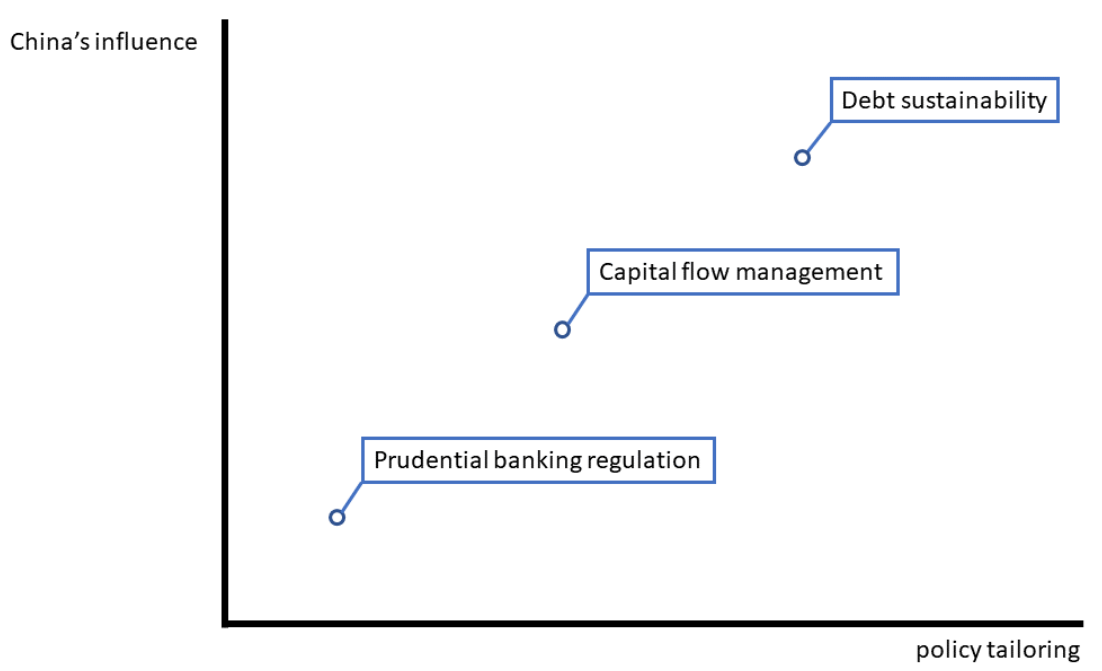

\subsection{Banking prudential regulation}

The post-crisis revision of global banking regulatory standards has not engendered a move towards a tailored approach. In fact, there is evidence that global standard-setting bodies place more emphasis on cross-border harmonization of prudential regulation than before. China's influence has also been limited: although Chinese regulatory authorities gained formal membership in all relevant global financial standard-setting bodies in 2009, analysts will be hard-pressed to attribute post-crisis discontinuities in financial regulation to Beijing's influence. However, a global debate on the purpose of shadow banking and its regulation has emerged in recent years, and China's role in a coalition of developing countries that advocate for a development-friendly regulatory approach merits attention.

Created in the 1970s, the Basel Committee on Banking Supervision has formulated a singular set of rules that govern the operations of internationally active banks in all member jurisdictions. Originally published in 1988 and revised in 2004 and again in 2012 (Basel I, II, and III respectively), the standards specify the minimum prudential requirements that banks must meet in order to achieve a certain resilience to economic shocks, no matter what their location or business model is. The global financial crisis highlighted how regulatory arbitrage within and across countries had undermined Basel Il's prudential function.

Scholars have analysed post-crisis financial regulatory reform efforts from a variety of perspectives, focusing on stringency, market-friendliness, or its intellectual underpinnings (Admati and Hellwig 2013; Baker 2013; Moschella and Tsingou 2013; Helleiner 2014). However, few have paid attention to the degree of cross-border harmonization and its repercussions for financial policies in developing countries. Even though the standards apply only to banks in the 27, mostly rich, member jurisdictions of the Basel Committee, they are of clear relevance for developing countries around the world. Jones and Zeitz (2017) show that adoption of Basel I, II, and III standards is widespread among countries of all income levels. The authors point out that the complexity of Basel rules can strain regulatory resources in developing countries. Moreover, their liberal underpinnings may also encumber state-interventionist strategies of financial sector development.

Incorporating lessons learned from the crisis, the new Basel III standard features stricter capital requirements and new rules to address previously neglected sources of risk. The Basel Committee has also developed a rigorous peer review mechanism (the Regulatory Consistency Assessment Program) to limit regulatory arbitrage (BCBS 2013). Thus, post-crisis reform exhibits greater harmonization, and the notion of tailoring Basel III to development stages and idiosyncratic country conditions is anathema to the Basel Committee.

Although Chinese representatives have participated in this process, there is little evidence that Chinese regulators have exerted significant influence in the negotiation of Basel III. As Kempthorne (2016) rightly points out, in the realm of financial regulation China currently can count neither on the market size nor expertise sufficient to be considered a leading jurisdiction. Moreover, the Chinese banking regulator has implemented Basel III such that it is not only conforming to but exceeding the global regulatory requirements (Walter 2016; Knaack 2017). 
However, there are emerging signs of discontinuity in China's acceptance of global financial standards. While regulators in Beijing supported the development of a stringent approach to "shadow banking" in the wake of the crisis, they are challenging this frame half a decade later. At the 2010 Summit in Seoul, G20 leaders endowed the Financial Stability Board (FSB) with the responsibility to strengthen the regulation and oversight of the shadow banking system (G20 2010). Shadow banking from the perspective of the FSB is a site of potential risk and regulatory arbitrage rather than a vehicle for more efficient credit allocation and financial inclusion.

Chinese studies of the domestic shadow banking system have consistently pointed to differences with its Western counterparts, highlighting the mismatches between the FSB understanding of shadow banking and the realities in China and other developing countries. While acknowledging the potential of risk accumulation, Chinese authorities started to promote the healthy growth and development of the shadow banking sector for the sake of financial inclusion and efficiency gains in credit intermediation (CASS 2013; PBOC 2013; M. Zhang, Gao, and Liv 2014).

In the eyes of Chinese financial experts, shadow banking regulation must take into account developmental stages. Instead of merely focusing on risk reduction, regulators should identify the financing needs of the real economy, encourage innovation of all financial institutions in order to improve the financial infrastructure and raise efficiency to provide greater opportunities for development (Ba 2010; Sheng and Soon 2016). This is a key departure from the FSB perspective on shadow banking and its regulation.

The dispute between the FSB frame and the one developed by Chinese policymakers reached the international stage in 2014 at one of the six regional consultative groups (RCG) that were created by the FSB to engage non-members in regulatory deliberations (Zheng 2016). The RCG for Asia issued a report that openly disputes the FSB frame on shadow banking as primarily a source of risk rather than a vehicle for economic improvement. This action acquires particular significance when considering that both developed and developing countries comprise the Regional Consultative Group, and that decisions such as this report are made by consensus (FSB RCG Asia 2014). Subsequent FSB reports (FSB 2016, 2017), however, do not support the view that shadow banking regulation should be tailored to developmental stages or country-specific circumstances.

In sum, post-crisis financial regulatory reform has not yet brought about an endorsement of a tailored approach to global prudential standards. There is little evidence that Chinese regulators adopted a developing country stance in Basel III negotiations. Chinese authorities have developed a more critical position vis-à-vis global shadow banking regulation in the Financial Stability Board. In this issue area, they may have played a key role as an advocate for a tailoring of global prudential rules to developmental needs in regional and global regulatory bodies. However, Beijing's actions have not yet altered the insistence of global standard setters on cross-border harmonization of shadow banking regulation.

\subsection{Capital flow management}

Devising appropriate policies towards transnational capital mobility has long been a difficult question of policy for developing countries. Although discretion to regulate capital flows has always been explicit in the IMF Articles of Agreement, the contentious politics of capital mobility at the IMF have long featured efforts to extend the Fund's formal jurisdiction so as to "contribute to policy consistency" (IMF 1984, cited in Kentikelenis \& Seabrooke 2017). This reflected the emergence of capital account liberalization in the 1980 s and 1990s as a foundational social norm of the IMF (Abdelal 2007).

Although developing countries were able to resist attempts at formal amendments (such as in 1997) enshrining the free movement of capital under Article VI, operational standards prioritized liberalization as a crucial aspect of financial development, thus precluding substantive tailoring of policy under IMF advice and Article IV bilateral surveillance mechanisms (IMF Independent Evaluation Office 2014). Far from seeking 'pragmatic approaches' (Prasad and Rajan 2008), the IMF consistently advocated the management of cross-border capital volatility by other means of domestic adjustment, resulting in a strong positive correlation between the receipt of IMF emergency and technical assistance and capital account liberalization (Joyce and Noy 2008; Kentikelenis, Stubbs, and King 2016).

The harmonization of this approach towards free capital mobility had significant implications for developing countries. ii Neoclassical generalizations assuming the universal needs of capital-scarce developing countries for attracting foreign capital-thus viewing restrictions on capital flows as inherently market-distorting-ignored the variety of country-specific costs and benefits that free capital mobility induced (Prasad and Rajan 2008). Harmonization of the formal global rules on capital mobility was justified by both senior technocrats and powerful high-income members as an important aspect of the Fund's developmental mission, with Stanley Fischer, the IMF's First Deputy Managing Director, arguing 
following the Asian Financial Crisis that capital account liberalization "is an inevitable step on the path of development, which cannot be avoided and therefore should be adapted to" (Fischer 1998).

Since the global financial crisis, governance of global capital flows has evolved considerably. The Fund has increasingly accepted China's practice of policy experimentation in its macroeconomic policy and progression of domestic and external financial reform (IMF 2010a, 2012b). In line with its emphasis upon tailoring global standards to its developmental needs, China has constructed a distinctive regime to manage its own capital flows that is sequenced, gradual, targeted, and reversible. Although admittedly imperfect, this 'non-traditional managed convertibility' (Zhou 2015, 6) enables specific avenues and channels of capital flows to be managed according to the specific circumstances at hand (McNally and Gruin 2017; Töpfer 2017).

China has also taken an important position alongside other BRICS coalition members in pressuring the IMF to move away from a harmonized and uniform view on capital account liberalization. China's growing leadership in the G20 was central to the BRICS efforts leading up to the 2011 communiqué on capital controls, reiterating the entitlement of states to regulate capital flows as they saw fit (G20 Information Centre 2011). This followed a series of calls by developing countries for the IFls to pay greater attention to the impact of excessive capital flows, including in the Seoul G20 Summit Declaration (G20 2010).

The IMF's change of policy stance on capital mobility commenced partially in response to these efforts, when Managing Director Dominic Strauss-Kahn sought a reassessment of the Fund's view on capital flows given the reinvigorated need articulated by developing countries to manage post-crisis capital flows. He was supported in this at the time by China's most senior Fund official Zhu Min, appointed in 2009 as Special Advisor to the Managing Director, and who urged deeper institutional recognition of the need to integrate globally uneven developmental processes and stages into the Fund's efforts to redress global monetary imbalances (Canaves 2010; Ma 2010).

The new 'institutional view' (IMF 2012c) began with a series of four papers from 2010-2012. (IMF 2010b, 2011 a, 2011b, 2012a). Staff economists recognized that volatile capital flows amplify emerging market financial fragility, as private market actors externalize the distortions that they generate in forex and capital markets (Korinek 2011 1). From this perspective, 'capital flow management measures' (CFMs) correct for market failures rather than act as distortions themselves, a view favoured by key developing countries as granting more flexibility in policy formation (K. P. Gallagher 2015). The broader implications for developing countries have been significant, with some going so far as to describe the 'normalization' of CFMs as the "single most important way in which policy space for development has widened in several decades" (Grabel 2011, 812).

Yet despite the IMF's remarkable volte face after decades of intransigence on the issue, these proposals for translating the new institutional view into a more comprehensive set of formal amendments were met with resistance from developing countries, again led by China and Brazil, who rejected the suggestion that the IMF should more formally codify when nations should and should not implement capital control measures (G-24 2011). Within the Fund, upon his elevation to the position of Deputy Managing Director in 2011, Zhu Min further echoed the concerns of developing countries at the executive board level about the strict harmonization of a new 'code of conduct' for capital flow management (BWP 2011).

The ongoing debate within the IMF is accordingly less about the substantive question of whether to liberalize capital accounts or not, and more concerned with the extent to which harmonization of policy should take place at the level of GFG and through the IMF particularly. When in 2013 the Fund issued operational guidelines to staff on capital mobility, it recognized the importance of "a sequenced approach that takes into account levels of development and country circumstances" (IMF 2013a, see also 2015).

As China rises gradually but steadily to greater monetary prominence, it is deploying its own distinct approach to the management of transnational capital flows and increasing its engagement in debates over the future of transnational monetary relations. Its growing influence not only precludes a return to universal norms and standards for capital flow management, but also deepens prospects for a more idiosyncratic and developmental approach to governing transnational capital mobility.

\subsection{Debt Sustainability Surveillance}

Since its introduction in 2005, the joint IMF-World Bank Debt Sustainability Framework (DSF) for LowIncome Countries (LICs) has been the "cornerstone" of the international community's assessment of risks to debt sustainability in LICs, playing "a critical role" in guiding borrowing and lending decisions (IMF 2017).

The DSF was intended to constrain imprudent lending and borrowing. Historical mistakes combined with episodes of imprudent lending and borrowing have engendered the necessity of a 
multilateral debt surveillance framework, exemplified in the IMF's debt limits policy and the World Bank's Non-Concessional Borrowing Policy. Especially in the wake of unprecedented debt relief initiatives such as the Heavily Indebted Poor Countries Initiative launched in 1996 and the 2005 Multilateral Debt Relief Initiative, stakes are high in making sure the hard-won gains from debt forgiveness are preserved and new borrowings do not lead to a new round of debt crises. This new wave of credit has been mainly driven by official lenders such as Ex-Im Banks and development banks from emerging economies and China in particular (Sender 2012). Despite the potential of such new lending for filling the vast financing gap, the World Bank warned that such loans could erode the gains of debt reliefs if they triggered a new round of unsustainable lending and borrowing (World Bank 2006). Where the World Bank's debt relief or grants could potentially cross-subsidize lenders that offer non-concessional loans to recipient countries, lenders such as China could be accused of free-riding on the existing debt forgiveness regime.

But a fundamental flaw of the DSF was that the stringency of its harmonized debt ceiling which adopted a simplistic harmonized standard that 'non-concessional' loans-which have a grant element lower than 35 percent and are thus more expensive-were more prone to debt distress. Breach would threaten their access to World Bank assistance, or even lead to the Bank's withdrawal from the country (World Bank 2006, ii). Furthermore, the DSF used just a single explanatory variable in in assessing a country's debt-carrying capacity-the Country Policy and Institutional Assessment (CPIA). CPIA is a universal benchmark for evaluating the quality of institutions and policies for all World Bank borrowing countries. The CPIA has been criticized by the World Bank's own Independent Evaluation Group for adopting "a one-size-fits-all approach" (Independent Evaluation Group 2010, 60), and a "uniform model" (Kanbur 2005) of development policy that is not supported by country experience and pays insufficient regard to specific development needs.

This strict harmonization of the DSF has been long been criticized by borrowing countries. In 2008 , Nouakchott Declaration urged "more flexibility in the application of the concessionality thresholds to reflect the development financing needs of African countries especially as it relates to infrastructure, and also take into account the profitability of each project" (IMF and World Bank African Caucus, 2008). Further the rule was so rigid and uniform that it had led to "an excessive rate of false alarms" in crisis prediction (IMF 2017, 49), and thus potentially unnecessarily curtailing developing countries' in seeking alternative financing sources (Tan 2006).

To redress such limitations, China has sought to reshape the rule so that it is tailored to different development conditions and takes into account country-specific circumstances. Officials have maintained that a more forward-looking assessment of the investment-growth nexus is necessary, since infrastructural development addresses growth bottlenecks, ultimately contributing to long term debt sustainability by initiating a virtuous circle of investment, growth and poverty reduction (Li 2007). China has also placed substantial pressure upon the IMF-World Bank by providing alternative and significant sources of longterm 'patient capital' through the China Development Bank and Ex-Im Bank and thus "more room to maneuver" (Kaplan 2016). iii It was estimated that China provided USD350 billion in official finance from 2000 to 2014 with the bulk comprising non-concessional finance instead of official development assistance, and with a much clearer focus on infrastructure (Dreher et al. 2017). Consequently, the DFS's threat of aid curtailment grew increasingly ineffective because of the rise of China as an alternative development finance provider. ${ }^{\text {iv }}$

In response to the mounting pressure from China and borrowing countries, the IMF and the World Bank reformed the DSF in 2009 and again in 2010. The revised framework moved away from the previous single design for concessionality requirements towards a menu of options that took into account the diversity of borrowing country circumstances-countries' macroeconomic and public financial management capacity and the extent of their debt vulnerabilities (World Bank 2010). As a result, within a sustainable borrowing envelope, borrowers should be able to tap the new sources of financing that are available to them.

China together with other emerging economies continued to push for a much bolder reform in the DSF via the G20. The G20 High Level Panel on Infrastructure-where Jin Liqun, then Chairman of the Board of Supervisors of China Investment Corporation and the current President of the Asian Infrastructure Investment Bank served as a key member-proposed a step further to systematically take into account "the efficiency of public investment" with a special emphasis on "transformational regional projects" in setting debt limits so that eligible countries and projects could benefit from the more flexible options (G20 $2011)$.

As a result, when the IMF conducted its debt limits policy review in April 2013, it removed the normative distinction between concessional and non-concessional loans. It recognized the constraints on borrowers of its rigid enforcement, and thus provided stronger safeguard to debt sustainability without unduly limiting developing countries' in securing adequate external funding. (IMF 2013b). In September 2017 , it further sought to strike "an appropriate balance" between providing borrowers early warnings of debt distress without unnecessarily constraining them (IMF 2017), proposing "tailored" stress tests 
including macroeconomic variable to take better account of country-specific features when assessing a country's debt-carrying capacity.

\section{Conclusion}

In this article we have provided a novel analysis to understanding the nature of China's increasing influence in global financial governance. Our central inquiry is to what extent the rules and standards of GFG are incorporating greater scope for tailoring to country-specific developmental needs due to China's rise in the wake of the global financial crisis. Our case studies provide early support for a subtle but significant deviation from harmonized rules and standards in GFG.

These findings raise significant theoretical and empirical questions for further research into the developmental implications of China's rise. First, we illustrate how China is influencing GFG through a number of channels such as extra-forum leverage, discursive argumentation within official forums, and intergovernmental coalition building. Further theoretical work on both the microfoundations and causal mechanisms through which China is exerting influence in GFG is warranted.

Secondly, our plausibility probe examined only three specific cases of GFG rules and standards where Chinese preferences for a tailored approach to development are evident. Empirical investigation of China's influence across other areas of GFG, such as emerging standards for macroprudential regulation, the regulation of domestic development banks, and long-term finance provision, will reveal deeper insights into the conditions under which Chinese policymakers push for tailored development. A detailed analysis of case-specific preferences and influence will provide a more fine-grained picture of the developmental implications of China's rise in global financial standard-setting.

Third, our arguments concerning greater tailoring in GFG also relate to the contested concept of 'developmental policy space' for national governments within global finance. Developmental policy space is broader and more ambiguous, involving considerations not just of the specific content of GFG rules and standards, but also the constraining and enabling effects of transnational markets and other external economic factors. Our delimited focus on tailoring in rules and standards paves the way for more rigorous investigation of how developmental policy space is changing alongside China's rise in GFG.

Greater scope for tailoring can be a mixed blessing: on the one hand, established governance frameworks run the risk of falling into a "race-to-the-bottom" competition among governments with more leeway than before. Harmonization can help to uphold the principle of equal treatment of its members, and it also deters informal undue political influence by removing discretionary power from international bureaucrats. On the other hand, the one-size-fits-all approach is problematic in preventing developing countries from addressing specific national conditions and experimenting with different development strategies. A tailored approach allows governments to creatively deploy this flexibility to accelerate the development process or buffer themselves against risks in their integration into the global economy. A rising China will play an increasingly important role in a transformation of GFG that will aim to reduce the risks and harness the benefits inherent in adopting a tailored approach to financial policies in developing countries. 


\section{References}

Abdelal, Rawi. 2007. Capital Rules: The Construction of Global Finance. Cambridge, MA: Harvard University Press.

Admati, Anat R., and Martin F. Hellwig. 2013. The Bankers' New Clothes: What's Wrong with Banking and What to Do about It. Princeton; Oxford: Princeton University Press.

Ang, Yuen Yuen. 2015. "Do Weberian Bureaucracies Lead to Markets or Vice Versa? A Coevolutionary Approach to Development." SSRN Scholarly Paper ID 2658202. Rochester, NY: Social Science Research Network. https://papers.ssrn.com/abstract=2658202.

—. 2016. How China Escaped the Poverty Trap. Ithaca, NY: Cornell University Press.

Ba, Shusong. 2010. 中国金融大末来 (China's Great Financial Future). Beijing, CN: Huawen Publishers.

Baker, Andrew. 2013. "The New Political Economy of the Macroprudential Ideational Shift." New Political Economy 18 (1): 112-139.

2014. "Transnational Technocracy and the Macroprudential Paradox." In Transnational Financial Regulation after the Crisis, edited by Tony Porter, 29-49. London, UK: Routledge.

BCBS. 2013. "Regulatory Consistency Assessment Programme (RCAP), Assessment of Basel III Regulations - China." Bank for International Settlements. http://www.bis.org/bcbs/implementation/12_cn.pdf.

Beeson, Mark, and Fujian Li. 2015. "What Consensus? Geopolitics and Policy Paradigms in China and the United States." International Affairs 91 (1): 93-109.

Blecher, Marc J., and Vivienne Shue. 1996. Tethered Deer: Government and Economy in a Chinese County. Stanford University Press.

Bremmer, Ian. 2010. The End of the Free Market: Who Wins the War between States and Corporations? New York, NY: Portfolio.

Breslin, Shaun. 2011. "The 'China Model' and the Global Crisis: From Friedrich List to a Chinese Mode of Governance?" International Affairs 87: 1323-43.

BWP. 2011. “Bretton Woods Update.” Update 76. Bretton Woods Project (BWP).

Canaves, Sky. 2010. "What to Make of Zhu Min's Role at IMF?” The Wall Street Journal, February 25, 2010. http://blogs.wsj.com/chinarealtime/2010/02/25/what-to-make-of-zhu-minsrole-at-imf/.

CASS. 2013. “Intermediate Research Report on the Shadow Banking System. 中国影子银行体 系研究报告（摘要）.”Beijing, CN: Institute of World Economics and Politics, Chinese Academy of Social Sciences. http://wenku.baidu.com/view/6672b21759eef8c75fbfb318.html.

Chang, Ha-Joon. 2002. Kicking Away the Ladder: Development Strategy in Historical Perspective. London: Anthem.

., ed. 2003. Rethinking Development Economics. London: Anthem Press.

Chang, Ha-Joon, and Ilene Grabel. 2005. Reclaiming Development: An Alternative Economic Policy Manual. 2. impr. Nova Scotia: Fernwood Publ. [u.a.].

Chen, and Barry Naughton. 2016. "A Dynamic China Model: The Co-Evolution of Economics and Politics in China." Journal of Contemporary China 0 (0): 1-17. https://doi.org/10.1080/10670564.2016.1206278. 
Dreher, Axel, Andreas Fuchs, Bradley Parks, Austin M. Strange, and Michael J. Tierney. 2017. “Aid, China, and Growth: Evidence from a New Global Development Finance Dataset." AidData Working Paper No. 46.

Ferdinand, Peter, and Jue Wang. 2013. "China and the IMF: From Mimicry towards Pragmatic International Institutional Pluralism.” International Affairs 89 (4): 895-910. https://doi.org/10.1111/1468-2346.12050.

Fischer, Stanley. 1998. "Capital-Account Liberalization and the Role of the IMF"." In Should the IMF Pursue Capital-Account Convertibility?, edited by Stanley Fischer, Richard Cooper, Rüdiger Dornbusch, Peter Garber, Carlos Massad, Jacques Polak, Dani Rodrik, and Savak Tarapore, 1-10. Princeton, NJ: Princeton Essays in International Finance.

FSB. 2016. "Thematic Review on the Implementation of the FSB Policy Framework for Shadow Banking Entities." Financial Stability Board. http://www.fsb.org/wpcontent/uploads/Shadow-banking-peer-review.pdf.

2017. "Global Shadow Banking Monitoring Report 2016." http://www.fsb.org/wpcontent/uploads/global-shadow-banking-monitoring-report-2016.pdf.

FSB RCG Asia. 2014. "Report on Shadow Banking." Financial Stability Board Regional Consultative Group Asia. http://www.fsb.org/wp-content/uploads/r_140822c.pdf.

G20. 2010. "The G20 Seoul Summit Declaration." http://www.g20.utoronto.ca/2010/g20seoul.pdf.

. 2011. “G20 High-Level Panel on Infrastructure Final Report.” Washington, D.C.: G20.

G20 Information Centre. 2011. "G20 Coherent Conclusions for the Management of Capital Flows Drawing on Country Experience as Endorsed by G20 Finance Ministers and Central Bank Governors." Cannes, FR: G20.

G-24. 2011. "G-24 Communiqué.” Washington, DC: Intergovernmental Group of Twenty-Four.

Gallagher, Kevin. 2015. "Countervailing Monetary Power: Re-Regulating Capital Flows in Brazil and South Korea." Review of International Political Economy 22 (1): 77-102.

Gallagher, Kevin P. 2015. "Contesting the Governance of Capital Flows at the IMF." Governance 28 (2): 185-198.

Grabel, Ilene. 2011. "Not Your Grandfather's IMF: Global Crisis, 'productive Incoherence' and Developmental Policy Space." Cambridge Journal of Economics 35 (5): 805-30.

Gruin, Julian. 2016. "The Social Order of Chinese Capitalism: Socio-Economic Uncertainty, Communist Party Rule and Economic Development, 1990-2000.” Economy and Society 45 (1): 24-50.

Güven, Ali Burak. 2016. "The World Bank and Emerging Powers: Beyond the MultipolarityMultilateralism Conundrum." New Political Economy 0 (0): 1-25. https://doi.org/10.1080/13563467.2017.1257596.

Heilmann, Sebastian. 2008. "From Local Experiments to National Policy: The Origins of China's Distinctive Policy Process." The China Journal 59: 1-30.

Helleiner, Eric. 2014. The Status Quo Crisis: Global Financial Governance After the 2008 Meltdown. Oxford, UK: Oxford University Press.

Helleiner, Eric, and Stefano Pagliari. 2011. "The End of an Era in International Financial Regulation? A Postcrisis Research Agenda.” International Organization 65: 169-200.

Henning, C. Randall, and Andrew Walter, eds. 2016. Global Financial Governance Confronts the Rising Powers: Emerging Perspectives on the New G20. Waterloo, ON: Centre for International Governance Innocation. https://www.cigionline.org/publications/global-financialgovernance-confronts-rising-powers-emerging-perspectives-new-g20.

Hirschman, Albert O. 1958. The Strategy of Economic Development. New Haven: Yale Univ. Pr. 
Horesh, Niv, and Kean Fan Lim. 2017. "China: An East Asian Alternative to Neoliberalism?” The Pacific Review 30 (4): 425-42. https://doi.org/10.1080/09512748.2016.1264459.

Ikenberry, G. John. 2008. “The Rise of China and the Future of the West: Can the Liberal System Survive?" Foreign Affairs 87: 23-37.

IMF. 1984. "Review of Experience with Multiple Exchange Rate Regimes." Staff Memorandum/84/64. Washington, DC: International Monetary Fund.

2010a. "People's Republic of China: 2010 Article IV Consultation-Staff Report." Washington, D.C.: International Monetary Fund.

2010b. “The Fund's Role Regarding Cross-Border Capital Flows." Washington, DC: International Monetary Fund.

2011a. "Recent Experiences in Managing Capital Inflows-Cross-Cutting Themes and Possible Policy Framework." Washington, DC: International Monetary Fund.

2011b. "The Multilateral Aspects of Policies Affecting Capital Flows-Background Paper." Washington, DC: International Monetary Fund.

2012a. "Liberalizing Capital Flows and Managing Outflows." Washington, DC: International Monetary Fund.

. 2012b. "People's Republic of China: 2012 Article IV Consultation-Staff Report." Washington, D.C.: International Monetary Fund.

2012c. "The Liberalization and Management of Capital Flows: An Institutional View." Washington, DC: International Monetary Fund.

2013a. "Guidance Note for the Liberalization and Management of Capital Flows." Washington, DC: International Monetary Fund.

2013b. "Public Information Notice: IMF Executive Board Reviews the Policy on Debt Limits in Fund-Supported Programs." Washington, D.C.: International Monetary Fund. http://www.imf.org/external/np/sec/pn/2013/pn1343.htm.

2015. "Managing Capital Outflows - Further Operational Considerations." Washington, DC: International Monetary Fund.

2017. "Review of the Debt Sustainability Framework in Low-Income Countries: Proposed Reforms." IMF Policy Paper. Washington, DC: International Monetary Fund.

IMF Independent Evaluation Office. 2014. "IMF Response to the Financial and Economic Crisis." Washington, D.C.: International Monetary Fund.

Independent Evaluation Group. 2010. “The World Bank's Country Policy and Institutional Assessment: An Evaluation.” World Bank.

Johnson, Chalmers. 1982. MITI and the Japanese Miracle: The Growth of Industrial Policy: 1925-1975. Stanford University Press.

Jones, Emily, and Alexandra Zeitz. 2017. "The Limits of Globalizing Basel Banking Standards." Journal of Financial Regulation.

Joyce, Joseph P., and Ilan Noy. 2008. “The IMF and the Liberalization of Capital Flows.” Review of International Economics 16 (3): 413-430.

Kahler, Miles. 2013. "Rising Powers and Global Governance: Negotiating Change in a Resilient Status Quo." International Affairs 89 (3): 711-29. https://doi.org/10.1111/14682346.12041.

Kanbur, Ravi. 2005. "Reforming the Formula: A Modest Proposal for Introducing Development Outcomes in IDA Allocation Procedures." Cornell University Centre for Economic Policy Research ( CEPR) Discussion Paper No. 4971. 
Kaplan, Stephen B. 2016. "Banking Unconditionally: The Political Economy of Chinese Finance in Latin America." Review of International Political Economy 23 (4): 643-76. https://doi.org/10.1080/09692290.2016.1216005.

Kempthorne, David. 2016. “China's Role in Financial Standard Setting after the 2007-2009 Financial Crisis: The Case of Basel III and Shadow Banking Reform." In Enter the Dragon: China in the International Financial System, edited by Domenico Lombardi and Hongying Wang, 353-84. Waterloo, ON, Canada: CIGI Press.

Kennedy, Scott. 2010. “The Myth of the Beijing Consensus.” Journal of Contemporary China 19: 46177.

Kentikelenis, Alexander E., Thomas H. Stubbs, and Lawrence P. King. 2016. "IMF Conditionality and Development Policy Space, 1985-2014." Review of International Political Economy 23 (4): 543-582.

Knaack, Peter. 2017. "An Unlikely Champion of Global Finance: Why Is China Exceeding Global Banking Standards?” Journal of Current Chinese Affairs 46 (2): 41-79.

Korinek, Anton. 2011. “The New Economics of Prudential Capital Controls: A Research Agenda." IMF Economic Review 59 (3): 523-61. https://doi.org/10.1057/imfer.2011.19.

Li, Ruogu. 2007. “A Proper Understanding of Debt Sustainability Issue in Developing Countries.” World Economics and Politics 4.

Lin, Justin Yifu. 2012. New Structural Economics: A Framework for Retbinking Development and Policy. The World Bank.

Lindauer, David L., Lant Pritchett, Dani Rodrik, and R. S. Eckaus. 2002. "What's the Big Idea? The Third Generation of Policies for Economic Growth [with Comments].” Economia 3 (1): $1-39$.

Ma, Dezhi. 2010. "Finance and Development." Finance and Development 47 (2). http://www.imf.org/external/pubs/ft/fandd/2010/06/zhu.htm.

McNally, Christopher. 2012. "Sino-Capitalism: China's Reemergence and the International Political Economy." World Politics 64: 741-76.

McNally, Christopher, and Julian Gruin. 2017. "Novel Pathways to Power? Contestation and Adaptation in China's Internationalization of the RMB." Review of International Political Economy Forthcoming.

Moschella, Manuela, and Eleni Tsingou. 2013. Great Expectations, Slow Transformations: Incremental Change in in Post-Crisis Regulation. ECPR Studies in European Political Science. Colchester: ECPR Press.

Mukand, Sharun W., and Dani Rodrik. 2005. "In Search of the Holy Grail: Policy Convergence, Experimentation, and Economic Performance." The American Economic Review 95 (1): 374 83.

Naughton, Barry. 1995. "China's Macroeconomy in Transition." The China Quarterly 144 (December): 1083-1104. https://doi.org/10.1017/S0305741000004744.

North, Douglass C. 1990. Institutions, Institutional Change and Economic Performance. Cambridge University Press.

Obstfeld, Maurice. 2009. "International Finance and Growth in Developing Countries: What Have We Learned?" IMF Staff Papers 56 (1): 63-111. https://doi.org/10.1057/imfsp.2008.32.

Oi, Jean C. 1995. "The Role of the Local State in China's Transitional Economy." The China Quarterly 144: 1132-1149.

PBOC. 2013. “China Financial Stability Report 2013.” People’s Bank of China.

Polanyi, Karl. 1957. The Great Transformation: The Political and Economic Origins of Our Time. Boston: Beacon Press. 
Prasad, Eswar S., and Raghuram G. Rajan. 2008. "A Pragmatic Approach to Capital Account Liberalization." The Journal of Economic Perspectives 22 (3): 149-172.

Prebisch, Raul. 1950. "The Economic Development of Latin America and Its Principal Problems." Santiago de Chile: CEPAL. http://archivo.cepal.org/pdfs/cdPrebisch/002.pdf.

Pritchett, Lant, and Michael Woolcock. 2004. "Solutions When the Solution Is the Problem: Arraying the Disarray in Development." World Development, Part special issue: Island Studies, 32 (2): 191-212. https://doi.org/10.1016/j.worlddev.2003.08.009.

Rodrik, Dani. 2001. “Trading in Illusions.” Foreign Policy, no. 123: 55-62.

2008. One Economics, Many Recipes: Globalization, Institutions, and Economic Growth. Princeton: Princeton University Press.

Rostow, W. W. 1959. “THE STAGES OF ECONOMIC GROWTH.” The Economic History Review 12 (1): 1-16. https://doi.org/10.1111/j.1468-0289.1959.tb01829.x.

Sender, Henny. 2012. "Finance: The Path to Power." Financial Times, August 20, 2012. https://www.ft.com/content/a6f91c46-d4c2-11e1-9444-00144feabdc0.

Sengupta, Rajeswari, and Abhijit Sen Gupta. 2016. "Capital Flows and Capital Account Management in Selected Asian Countries." Global Financial Governance Confronts the Rising Powers: Emerging Perspectives on the New G20, 29.

Shen, Xiaoxiao, and Kellee S. Tsai. 2016. "Institutional Adaptability in China: Local Developmental Models Under Changing Economic Conditions.” World Development 87 (Supplement C): 107-27. https://doi.org/10.1016/j.worlddev.2016.06.010.

Sheng, Andrew, and Ng Chow Soon. 2016. Shadow Banking in China: An Opportunity for Financial Reform. Hoboken: John Wiley \& Sons.

Sohn, Injoo. 2013. "Between Confrontation and Assimilation: China and the Fragmentation of Global Financial Governance." Journal of Contemporary China 22 (82): 630-48. https://doi.org/10.1080/10670564.2013.766384.

Steinfeld, Edward. 2010. Playing Our Game: Why China's Economic Rise Doesn't Threaten the West. Oxford, UK: Oxford University Press.

Stiglitz, Joseph E. 2010. The Stiglitz Report: Reforming the International Monetary and Financial Systems in the Wake of the Global Crisis. New Press, The.

Tan, Celine. 2006. "Who's' Free Riding'? A Critique of the World Bank's Approach to NonConcessional Borrowing in Low Income Countries." http://wrap.warwick.ac.uk/id/eprint/1897.

Töpfer, Laura-Marie. 2017. "Institutional Change in Chinese Cross-Border Finance: Foreign Investors, the Party-State and Power Resources." Review of International Political Economy 0 (0): $1-32$.

Wade, Robert H. 2004. Governing the Market: Economic Theory and the Role of Government in East Asian Industrialization; with a New Introduction by the Author. 2. pbk. ed. Princeton, NJ: Princeton Univ. Press.

Walder, Andrew G. 1995. "Local Governments as Industrial Firms: An Organizational Analysis of China's Transitional Economy." American Journal of Sociology 101 (2): 263-301.

Walter, Andrew. 2016. "Emerging Countries and Basel III: Why Is Engagement Still Low?" In Global Financial Governance Confronts the Rising Powers, edited by C. Randall Henning and Andrew Walter, 179-210. Waterloo: CIGI.

World Bank. 2006. "IDA Countries and Non-Concessional Debt: Dealing With the 'Free Rider' Problem in IDA-14 Grant-Recipient and Post-MDRI Countries."

2010. “IDA’s Non-Concessional Borrowing Policy: Progress Update.” Washington, D.C.: World Bank IDA Resource Mobilization Department. 
Xiao, Ren. 2015. "A Reform-Minded Status Quo Power? China, the G20, and Reform of the International Financial System." Third World Quarterly 36 (11): 2023-43. https://doi.org/10.1080/01436597.2015.1078232.

Xu, Jiajun. 2017. Beyond US Hegemony in International Development: The Contest for Influence at the World Bank. Cambridge, United Kingdom: Cambridge University Press.

Zhang, Falin. 2017. "Holism Failure: China's Inconsistent Stances and Consistent Interests in Global Financial Governance." Journal of Contemporary China 26 (105): 369-84. https://doi.org/10.1080/10670564.2016.1245893.

Zhang, Ming, Haihong Gao, and Dongmin Liu. 2014. Revealing the Chinese Shadow Banking System (透视中国影子银行体系). Beijing: Chinese Academy of Social Sciences Press.

Zheng, Liansheng. 2016. "Shadow Banking in China and International Regulatory Cooperation." In Global Financial Governance Confronts the Rising Powers, edited by C. Randall Henning and Andrew Walter, 307-30. Waterloo: CIGI.

Zhou, Xiaochuan. 2015. "IMFC Statement." Statement by the Honorable Zhou Xiaochuan, Governor of the IMF for China, to the Thirty-First Meeting of the International Monetary and Financial Committee. Washington, DC: International Monetary Fund.

\section{Author bios:}

\section{Dr. Julian Gruin}

Julian Gruin is Assistant Professor of Transnational Governance at the University of Amsterdam, and an ESRC FRL Fellow at the University of Warwick. His research focuses on global financial governance and Chinese political economy, and the evolving nature of power in the global economy. His monograph Communists Constructing Capitalism is forthcoming with Manchester University Press.

\section{Dr. Peter Knaack}

Peter Knaack is Postdoctoral Research Fellow in Global Economic Governance at the Blavatnik School of Government, University of Oxford. His research focuses on global financial governance. He has written and published on transatlantic coordination failure in derivatives regulation, the politics of global banking regulation, and the growing tension between nation-states and transgovernmental networks over the authority to govern cross-border economic activity.

\section{Dr. Jiajun Xu}

Jiajun Xu is Assistant Professor and the Executive Deputy Dean of the Institute of New Structural Economics at Peking University. Her research focuses on development financing and global economic governance. Her academic monograph Beyond US Hegemony in International Development was published by Cambridge University Press in 2017. 
$i$ The research presented in this article has greatly benefited from the feedback we have received from our colleagues in China and Europe. In particular, we are grateful to Huang Wei, Alexander Kentikelenis, Wei Liu, Daniel Mügge, Yan Shen, Andrew Walter, Ming Zhang, Weiqiang Zhang, and the participants of the PETGOV Seminar at the University of Amsterdam, the ENLIGHTEN \& Fickle Formulas Workshop, the China in Global Governance Conference in Leiden, and the Faculty Seminar at the School of Government in Oxford. This research was made possible thanks to generous funding provided by the UK Economic and Social Research Council (Grants ES/L01 2375/1 and ES/NO01982/1), the National Natural Science Foundation of China-Data Center for Management Science at Peking University (2017KEY06), the National Social Science Fund of China (17BJL124)and the John Fell Fund of Oxford University Press (Grant 162/073).

ii A vast literature exists on both the political economy and developmental implications of capital account liberalization. On the former, especially in relation to developing countries, see Gallagher (2015); on the latter see Prasad and Rajan (2008), Obstfeld (2009), and with reference to Asia, Sengupta and Gupta (2016)

iii CDB's total assets reached USD1.9 trillion in 2015, much larger than the total assets combined of the World Bank and regional development banks. (Various annual reports).

iv Interview with World Bank Senior Management Official, May 2012, Washington DC. 